\title{
KESIAPAN PENEGAK HUKUM \\ DI KABUPATEN PAMEKASAN DALAM PEMBERLAKUAN \\ UNDANG-UNDANG NOMOR 11 TAHUN 2012 TENTANG SISTEM PERADILAN PIDANA ANAK
}

\author{
Umi Supraptiningsih \\ Sekolah Tinggi Agama Islam Negeri (STAIN) Pamekasan \\ e-mail: umisupraptinigsih@yahoo.com
}

\begin{abstract}
ABSTRAK
Lahirnya Undang-Undang Nomor 11 Tahun 2012 tentang Sistem Peradilan Pidana Anak (Lembaran Negara RI Tahun 2012 Nomor 153 Tambahan Lembaran Negara RI Nomor 5332) merupakan harapan bagi anak-anak yang berhadapan dengan hukum baik sebagai pelaku maupun sebagai korban untuk tetap mendapatkan hak-haknya. Hal penting yang diatur dalam UU-SPPA adalah pelaksanaan diversi. Hal-hal yang harus dipersiapkan dalam pemberlakuan UU-SPPA ada dua aspek, yaitu fisik dan non fisik. Persiapan secara fisik berupa sarana dan prasarana, yang selama ini masih belum ada Pemerintah daerah harus mempersiapkan lembaga-lembaga seperti Lembaga Pembinaan Khusus Anak, Lembaga Penempatan Anak Sementara, Lembaga Penyelenggaraan Kesejahteraan Sosial. Sedangkan persiapan non fisik meliputi penegak hukum yang mempunyai sertifikat sebagai penyidik anak, jaksa anak, dan hakim anak. Sedangkan faktor penghambat atas pemberlakuan UU-SPPA yang paling dominan ada pada UU-SPPA itu sendiri karena masih banyak aturan yang memerlukan petunjuk teknis untuk melaksanakannya, seperti aturan tentang prosedur diversi. Jika diversi merupakan amanat dalam UU-SPPA, maka selama lembaga-lembaga baru belum tersedia, maka pelaksanaan diversi akan mengalami hambatan. Demikian juga selama belum tersedia penegak hukum khusus anak, maka amanat UU-SPPA juga tidak akan terlaksana.
\end{abstract}

Kata Kunci: kesiapan, penegak hukum, Undang-Undang Nomor 11 Tahun 2012.

\section{ABSTRACT}

The establishment of Law of Number 11, 2012 about the system of children penal judgment (government gazette 2012 number 153 and additional government gazette number 5332, abbreviated UU-SPPA) is "a hope" for children facing the law both as doers or victims to get their rights. The important thing arranged in UU-SPPA is the completion of children penal from penal judgment process out of penal judgment. There are two aspects to prepare in establishing UU-SPPA, namely physical and non physical. The local governmet has to prepare the institutions such as Lembaga Pembinaan Khusus Anak, Lembaga Penempatan Anak Sementara, Lembaga Penyelenggaraan Kesejahteraan Sosial. This law accomodates children interest and protection that has given the completion of children cases facing the law. While the dominant inhibiting factor is in UU-SPPA its self since there are so many rules that need technical instructions to implement, such as the rule of diversion procedure. If the diversion is a mandate in UU-SPPA and the new institutions are not available so it will make the establishment of diversion facing obstacle. Moreover, if there is no children law holder, the mandate of SPPA will not also be implemented.

Keywords: readiness, law enforcement, Law No. 11 of 2012. 


\section{PENDAHULUAN}

Banyaknya persoalan sosial yang jika kita tarik dengan penyelesaian hukum dapat berakibat pada terabaikannya hak-hak perorangan atau individu, sedangkan hak-hak perorangan tersebut harus mendapatkan perlindungan dari negara. Terutama perorangan tersebut adalah mereka yang secara hukum belum mempunyai kecakapan untuk bertindak sendiri dalam memperjuangkan hak-haknya, bahkan dapat dikategorikan sebagai korban, seperti misalnya anak-anak yang masih di bawah umur.

Pada Pasal 27 ayat (1) Undang-Undang Dasar Tahun 1945 menyatakan bahwa, segala warga negara bersamaan kedudukannya di dalam hukum dan pemerintahan dan wajib menjunjung hukum dan pemerintahan itu dengan tidak ada kecualinya. Artinya bahwa semua Warga Negara Indonesia tanpa ada perbedaan apapun mempunyai hak yang sama untuk mendapatkan perlindungan hukum. Dalam Pasal 1 ayat (3) UUD 1945 juga menegaskan bahwa negara Indonesia adalah negara hukum. Konsekuensi dari pasal tersebut, maka negara harus menjadikan hukum sebagai panglima dalam kehidupan berbangsa dan bernegara.

Undang-undang memberikan perlindungan terhadap anak, terdapat di dalam salah satu Pasal 1 ayat (2) Kitab Undang-Undang Hukum Perdata yang menyatakan bahwa anak yang ada dalam kandungan seorang perempuan, dianggap sebagai telah dilahirkan, bilamana juga kepentingan si anak menghendakinya. Mati sewaktu dilahirkan, dianggaplah ia tak pernah ada. Dari pasal tersebut menegaskan bahwa undangundang memberikan perlindungan terhadap anak mulai anak tersebut masih berupa janin.

Negara sangat peduli terhadap anak-anak untuk dapat mewujudkan hak-haknya karena selain anak-anak sebagai generasi penerus bangsa, anak-anak juga sangat rentan menjadi korban. Bahkan yang menjadi penyebab atas hilangnya hak-hak anak tersebut lebih banyak adalah orang-orang yang seharusnya berkewajiban untuk memberikan perlindungan terhadap anak-anak. Pengaturan terhadap perlindungan anak diatur lebih lanjut dalam berbagai peraturan perundang-undangan antara lain dalam Undang-Undang Nomor 23 Tahun 2002 tentang Perlindungan Anak (yang selanjutnya disebut Undang-Undang Perlindungan Anak).

Terdapat kewajiban yang menjadi tanggung jawab bersama atas perlindungan anak, pada Pasal 20 Undang-Undang Perlindungan Anak menyatakan bahwa negara, pemerintah, masyarakat, keluarga dan orangtua berkewajiban dan bertanggungjawab terhadap penyelenggaraan perlindungan anak. Peranan orangtua, masyarakat dan negara dalam memberikan perlindungan kepada anak sangat dibutuhkan dalam rangka tindakan prefentif maupun represif. Marilah kita lihat potret mereka di berbagai media, anak-anak kita tidak sedikit yang menjadi korban peredaran dan pengguna narkoba, mencuri, dan yang marak terjadi di tahun 2012 sampai tahun 2013 ini anak-anak melakukan persetubuhan dengan sesama temannya dan dilakukan secara bergilir, bahkan membuat video pornografi dan pelakunya dalam video mereka sendiri bersama temannya (Anak dampingan Pusat Pelayanan Terpadu Pemberdayaan Perempuan dan Anak (P2TP3A) Kab. Pamekasan).

Peranan orangtua, yang lebih banyak dalam berkomunikasi dan berinteraksi dengan anak untuk terus memberikan bimbingan, nasihat dan perhatian. Negara sangat dibutuhkan untuk dapat mengatasi persoalan-persoalan anak melalui peraturan perundangundangan, menyiapkan alat penegak hukum khusus anak-anak yang berhadapan dengan hukum yaitu alat penegak hukum yang mempunyai sensitifitas terhadap anak. Begitu pula memberikan sosialisasi kepada masyarakat, bahwa anak-anak adalah tanggung jawab kita bersama, karena tidak jarang pelabelan yang diberikan oleh masyarakat terhadap anak-anak yang berhadapan dengan hukum bahkan anak-anak mantan napi justru akan membuat anak-anak menjadi frustasi.

Undang-Undang Nomor 39 Tahun 1999 tentang Hak Asasi Manusia telah mengatur secara umum mengenai hak anak, serta pelaksanaan kewajiban dan tanggung jawab orangtua, keluarga, masyarakat, pemerintah, dan negara untuk memberikan perlindungan kepada anak. Sebagaimana pula dalam Undang-Undang Perlindungan Anak, dalam penjelasan umumnya menyatakan bahwa undang-undang ini menegaskan pertanggungjawaban orangtua, keluarga, masyarakat, pemerintah dan negara merupakan rangkaian kegiatan yang dilaksanakan secara terus menerus demi terlindunginya hak-hak anak. Rangkaian kegiatan tersebut harus berkelanjutan dan terarah guna menjamin pertumbuhan dan perkembangan anak, baik fisik, mental, spiritual, maupun sosial. Tindakan ini dimaksudkan untuk mewujudkan kehidupan terbaik bagi anak yang diharapkan sebagai penerus bangsa 
yang potensial, tangguh, memiliki nasionalisme yang dijiwai oleh akhlak mulia dan nilai Pancasila serta kemauan keras menjaga kesatuan dan persatuan bangsa-bangsa.

Pada kenyaaannya era sekarang ini tingkat kenakalan anak sudah memasuki ambang batas yang sangat memprihatinkan. Dari hari ke hari tingkat kenakalan itu bukannya menurun akan tetapi justru terus meningkat, baik anak-anak itu berposisi sebagai pelaku tindak pidana maupun korban. Demikian juga jenis kenakalan yang dilakukan anak juga semakin kompleks dan memprihatinkan, mulai dari pencurian, perkelahian, persetubuhan, minuman keras (mabukmabukan), bahkan sampai narkoba. Kenakalan tersebut biasanya diawali dari tingkah laku menyimpang yang disebabkan oleh berbagai faktor internal dan eksternal. Secara eksternal, dampak negatif dari pembangunan, derasnya globalisasi dalam bidang teknologi, informasi dan komunikasi, dan kebutuhan ekonomi ternyata dapat menjadi pemicu anak melakukan tindak pidana. Secara internal, kondisi kepribadian anak yang masih labil menjadi pangkal tingkah laku menyimpang anak (Sri Sutatiek, 2013:60).

Problem-problem tersebut juga terjadi di Pamekasan, setidaknya dapat dilihat dari data di unit Perlindungan Perempuan dan Anak (yang selanjutnya disingkat PPA) Polres Pamekasan. Pada tahun 2012 terdapat data 23 kasus tentang anak-anak yang berhadapan dengan hukum, 7 kasus diantaranya dapat diselesaikan melalui mediasi (data di unit PPA Polres Pamekasan). Hal ini berarti anak-anak yang berhadapan dengan hukum harus terus menyelesaikan permasalahannya melalui jalur litigasi atau peradilan. Sebagian besar mereka harus menjalani masa penahanan baik di kepolisian maupun kejaksaan, dan bahkan tidak jarang putusan hakim juga menjatuhkan pidana penjara dalam waktu yang tidak singkat. Pada saat anak-anak menghadapi kasus hukum itu, mereka akan kehilangan hak-haknya diantaranya hak untuk mendapatkan pendidikan, perlindungan, kesehatan, dan hak-hak lain yang merupakan hak dasar yang harus mereka peroleh sesuai dengan usianya.

Sebagai contoh kasus yang dialami oleh IM (siswa SLTA kelas 1), gara-gara dia mencuri uang bapak kosnya dia harus menjalani proses hukum layaknya orang dewasa yang melakukan pencurian. Meskipun mediasi sudah dilakukan dan orangtua Imam sudah mengembalikan sebagian besar tingkat kerugian yang diderita korban, putusan hakim tetap dirasakan berat yaitu 1 tahun 2 bulan. Kasus lain dialami oleh KY (siswa SLTA kelas 3) yang melakukan persetubuhan dengan pacarnya. Pada saat kasusnya ditangani oleh unit PPA Polres Pamekasan, KY sedang mengikuti Ujian Nasional (UN) dan tetap harus menjalani proses hukum. Dia mendapat pengawalan polisi karena sedang menjalani masa penahanan di Polres Pamekasan dan putusan hakim pun cukup tinggi, yaitu 1 tahun 6 bulan. Demikian juga kasus yang dialami oleh BL (siswa SLTP baru saja lulus, usia 16 tahun). Dia berencana melanjutkan sekolah ke jenjang SLTA di Kota Pamekasan. Pada saat pendaftaran, dia menginap di rumah sepupunya dan menurut pengakuannya dia tidak pernah tahu kalau sepupunya itu pengguna narkoba. Pada saat itulah nasibnya kurang beruntung, dia yang hanya ikut-ikutan karena dibujuk rayu oleh sepupunya untuk ikut pesta narkoba, BL yang masih tergolong anak di bawah umur tersebut diperlakukan sama dengan sepupunya sebagai pengguna narkoba saat polisi melakukan penggerebekan.

Paparan data tentang kasus-kasus hukum yang dialami oleh anak-anak tersebut merupakan contoh kecil dari kasus-kasus anak yang terjadi di wilayah hukum Kabupaten Pamekasan karena sebenarnya masih terdapat banyak kasus-kasus hukum yang dialami oleh anak-anak di Pamekasan yang tidak mungkin untuk ditulis seluruhnya. Meskipun demikian, anak-anak itu tetap harus mendapatkan dukungan dan bimbingan karena mereka harus tetap mempersiapkan masa depannya. Jika tidak, sangat mungkin mereka akan menjadi terpuruk dan bahkan anak-anak itu akan menjadi sangat frustasi karena selain mereka mendapatkan sanksi hukum pidana juga mendapatkan sanksi dari masyarakat, diantaranya pelabelan-pelabelan negatif sebagai anak nakal atau anak mantan napi bagi pelaku dan pezina atau anak bispak atau habis pakai bagi korban. Hal yang sangat dikhawatirkan adalah, jika pelabelan-pelabelan negatif itu membuat anak kehilangan kepercayaan diri.

Anak-anak tersebut mau tidak mau berhadapan dengan hukum untuk mempertanggungjawabkan perbuatannya, bagaimana dengan sistem hukum di Indonesia dalam melakukan pemeriksaan, penuntutan dan pemutusan anak-anak yang berhadapan dengan hukum. Dalam perkembangan sistem hukum di Indonesia yang merupakan sistem warisan dari negara jajahan Belanda dan di sisi lain juga tidak lepas dari pengaruh global sistem hukum yang ada di dunia, maka beragam sistem hukum yang diterapkan di dunia 
peradilan di Indonesia. Disatu sisi diterapkannya civil law system namun di sisi yang lain juga mengadopsi common law system. Kelaziman di Indonesia, hakim yang satu memakai undang-undang sebagai dasar putusannya sedangkan hakim lainnya memakai rasa atau keyakinan sebagai dasar keputusannya dan ada pula yang menggunakan hukum adat dan bahkan ada yang menggunakan yurisprudensi sebagai satu-satunya acuan untuk mengambil keputusan. Hal ini sejalan dengan ketentuan dalam Undang-Undang Nomor 48 Tahun 2009 tentang Kekuasaan Kehakiman yang secara jelas menyatakan bahwa hakim wajib menggali, mengikuti dan memahami nilai yang hidup dalam masyarakat.

Terdapat 3 (tiga) aliran yang mempengaruhi sistem hukum di dunia peradilan, yaitu: Pertama, aliran legisme atau legal positivism, yang mana hakim berperan hanya melakukan pelaksanaan undang-undang (Wetstoepassing); Kedua, aliran freie rechtsbewegung, yang mana hakim bertugas untuk menciptakan hukum (Rechtsschepping) yang tidak terikat dengan undang-undang; Ketiga, aliran Rechtsvinding, dalam hal mana hakim mempunyai kebebasan yang terikat (gebonden-vrijheid) atau bisa diartikan keterikatan yang bebas (vrije-gebondenheid) (Sabian Utsman, 2008:72). Pengaruh tiga aliran besar tersebut yang kemudian dapat memberikan gambaran dimana sebenarnya posisi sistem hukum Indonesia Sistem hukum Indonesia lebih didominasi oleh aliran Rechtsvinding atau legal realism dengan cara dan karakteristik budaya bangsa Indonesia (walaupun tidak ada yang mempertegas) (Sabian Utsman, 2008:73).

Indonesia sesungguhnya lebih dekat dengan common law system, hal ini sangat beralasan karena masyarakat Indonesia dan hukum kebiasaan (customary law) begitu bertumbuh kembangnya hidup berakar pinak di masyarakat (living law) yang ada bersamasama dengan budaya dan agama (terlebih agama Islam) membuat semakin dekat dengan common law system ketimbang dengan roman law system.

Bagaimana dengan penemuan hukum yang berkaitan dengan isu hukum, dalam pola civil law system yang mengutamakan legislasi sehingga langkah dasar pola nalar yang dikenal sebagai reasoning based on rules adalah penelusuran peraturan perundangundangan yang dibuat oleh lembaga negara atau pejabat yang berwenang yang isinya mengikat secara umum, langkah ini merupakan langkah pertama dikenal sebagai statute approach. Berikutnya adalah langkah kedua yang mengidentifikasi norma. Rumusan norma merupakan suatu proposisi, sesuai dengan hakikat proposisi, norma terdiri atas rangkaian konsep. Untuk memahami norma harus diawali dengan memahami konsep. Inilah langkah ketiga yang dikenal dengan conceptual approach (Philipus M. Hadjon dan Tatiek Sri Djatmiati, 2005:42-43).

Berkaitan dengan pemidanaan anak, berbagai peraturan dan konvensi telah menempatkan anak-anak yang berhadapan dengan hukum merupakan anak-anak yang harus tetap mendapatkan hak-haknya, bentukbentuk penangkapan, penahanan dan pemidanaan adalah upaya hukum terakhir (ultimum remedium), sebagaimana Konvensi Internasional tentang Hak-hak Anak di dalam Pasal 3 menyatakan bahwa dalam semua tindakan yang menyangkut anak, baik yang dilakukan oleh lembaga-lembaga kesejahteraan sosial pemerintah atau swasta, lembaga pengadilan, lembaga pemerintah atau badan legislatif, kepentingan terbaik bagi anak harus dijadikan pertimbangan utama bagi kepentingan anak dalam kehidupan dalam lingkup keluarga dan masyarkat.

Hukum progesif menawarkan bentuk pemikiran dan penegakan hukum yang tidak subsmisif terhadap sistem yang ada tetapi lebih afirmatif (affirmatiflaw enforcement). Dilain pihak, hukum progresif melihat tujuan-tujuan lain seperti tujuan sosial dan konteks sosial. Aksi-aksi afirmatif didukung oleh keinginan untuk mendayagunakan hukum bagi kepentingan rakyat di atas semata-mata pengutamaan individu. Untuk itu dibutuhkan keberanian untuk membebaskan diri dari dominasi absolut asas dan doktrin liberal (Satjipto Rahardjo, 2009:142). Menurut perspektif hukum di Indonesia yang telah diawali dengan berlakunya Undang-Undang Nomor 4 Tahun 1979 tentang Kesejahteraan Anak yang kemudian secara umum ditindaklanjuti oleh Undang-Undang Nomor 39 Tahun 1999 tentang Hak Asasi Manusia, dan baru dapat direalisasikan secara khusus dengan adanya Undang-Undang Perlindungan Anak.

Undang-Undang Perlindungan Anak secara materiil sudah memberikan perlindungan yang luas terhadap anak-anak tidak terkecuali anak-anak yang berhadapan dengan hukum, namun secara formal dalam pelaksanaan undang-undang tersebut masih belum dilaksanakan sebagaimana yang menjadi tujuan undang-undang.

Dalam pelaksanaan Undang-Undang Perlindungan Anak, bentuk-bentuk penangkapan, penahanan dan 
pemidanaan anak adalah hal yang harus menjadikan keputusan terakhir (ultimum remedium), serta diharapkan dalam penanganan kasus-kasus anak yang berhadapan dengan hukum dapat dilakukan restroaktif justice, sehingga penegak hukum dapat memberikan diversi.

Pada Pasal 16 Undang-Undang Perlindungan Anak memberikan ketentuan tentang anak-anak yang berhadapan dengan proses hukum, bahwa anak berhak: 1. memperoleh perlindungan dari sasaran penganiayaan, penyiksaan atau penjatuhan hukuman yang tidak manusiawi; 2 . memperoleh kebebasan sesuai dengan hukum; 3. Penangkapan, penahanan atau tindak pidana penjara anak hanya dilakukan apabila sesuai dengan hukum yang berlaku dan hanya dapat dilakukan sebagai upaya terakhir.

Pada Pasal 17 Undang-Undang Perlindungan Anak menyatakan bahwa: 1. Setiap anak yang dirampas kebebasannya berhak untuk: a. Mendapatkan perlakuan secara manusiawi dan penempatannya dipisahkan dari orang dewasa; b. Memperoleh bantuan hukum atau bantuan lainnya secara efektif dalam setiap tahapan upaya hukum yang berlaku, misalnya bimbingan sosial dari pekerja sosial, konsultasi dari psikolog dan psikiater atau bantuan dari ahli bahasa; c. Membela diri dan memperoleh keadilan di depan pengadilan anak yang objektif dan tidak memihak dalam bidang tertutup untuk umum; 2. Setiap anak yang menjadi korban atau pelaku kekerasan seksual atau yang berhadapan dengan hukum berhak dirahasiakan.

Pada Pasal 18 Undang-Undang Perlindungan Anak, menyatakan bahwa setiap anak yang menjadi korban atau pelaku tindak pidana berhak mendapatkan bantuan hukum dan bantuan lainnya termasuk bantuan medis, sosial, rehabilitasi, vokasional dan pendidikan.

Pada Pasal 64 Undang-Undang Perlindungan Anak, menyatakan bahwa Pertama, perlindungan khusus bagi anak yang berhadapan dengan hukum meliputi anak yang berkonflik dengan hukum dan anak korban tindak pidana merupakan kewajiban dan tanggung jawab pemerintah dan masyarakat. Kedua, perlindungan khusus bagi anak yang berhadapan dengan hukum dilakukan melalui: 1. Perlakuan atas anak secara manusiawi sesuai dengan martabat dan hak-hak anak; 2. Penyediaan petugas pendamping khusus bagi anak sejak dini; 3. Penyediaan sarana dan prasarana khusus; 4. Penjatuhan sanksi yang tepat untuk kepentingan yang terbaik bagi anak; 5 . Pemantauan dan pencatatan terus menerus terhadap perkembangan anak yang berhadapan dengan hukum; 6 . Pemberian jaminan untuk mempertahankan hubungan dengan orangtua atau keluarga; 7. Perlindungan dari pemberitaan identitas melalui media massa dan untuk menghindari labelisasi.

Ketiga, Perlindungan khusus bagi anak yang menjadi korban tindak pidana, dilaksanakan melalui: 1. upaya rehabilitasi baik dalam lembaga maupun di luar lembaga; 2. upaya perlindungan dari pemberitaan identitas melalui media massa dan untuk menghindari labelisasi; 3. pemberian jaminan keselamatan bagi sanksi korban dan sanksi ahli baik fisik, mental maupun sosial; 4. Pemberian aksesibilitas untuk mendapatkan informasi mengenai perkembangan perkara.

Sedangkan Kitab Undang-Undang Hukum Pidana, memberikan pengaturan terhadap anak-anak yang berhadapan dengan proses hukum, yang diatur dalam Pasal 45, 46, dan 47 KUHP.

Lahirnya Undang-Undang Nomor 11 Tahun 2012 tentang Sistem Peradilan Pidana Anak (Lembaran Negara RI Tahun 2012 Nomor 153 Tambahan Lembaran Negara RI Nomor 5332, selanjutnya disingkat UU-SPPA) pada tanggal 30 Juli 2012 merupakan undang-undang yang diharapkan dapat memberikan perlindungan kepada anak-anak yang berhadapan dengan hukum. Pengesahan UU-SPPA merupakan langkah maju dalam penanganan anak yang berhadapan dengan hukum, yang mana undang-undang tersebut setidaknya telah memperbaiki sejumlah hal dari tujuh kelemahan dalam Undang-Undang Nomor 3 Tahun 1997 tentang Pengadilan Anak. Asas yang paling mendasar dalam UU-SPPA adalah keadilan restorative atau restroaktif justice yang selanjutnya penegak hukum dapat melakukan diversi.

Dengan mengedepankan musyawarah mufakat dengan cara pemulihan kerugian yang dialami korban dan pelaku lebih dikedepankan daripada hukuman penjara. Hukuman yang diterapkan terhadap anak yang berhadapan dengan hukum bertujuan mendidik, memberikan pembinaan dan bukan ajang membalas dendam, upaya yang demikian difasilitasi oleh negara melalui penegak hukum.

UU-SPPA mengadopsi sistem diversi artinya penyelesaian kasus secara kekeluargaan di luar pengadilan lebih diutamakan daripada proses peradilan atau mengalihkan proses pidana dalam persidangan menjadi di luar persidangan. Penegak hukum nanti akan memperoleh ruang lebih besar untuk mendamaikan dua pihak berperkara yang salah satu atau dua pihak 
adalah anak-anak yang melakukan pelanggaran hukum dengan ancaman hukuman kurang dari tujuh tahun dan bukan merupakan pengulangan tindak pidana (Pasal 7 UU-SPPA). Upaya diversi wajib dilakukan pada tingkat penyidikan, penuntutan, dan pemeriksaan perkara anak di Pengadilan Negeri. Sehingga yang sangat berperan sebagai mediator dalam diversi adalah penyidik polisi, jaksa penuntut umum, dan hakim. Bila pada tahap penyidikan tidak berhasil, maka jaksa sebagai penuntut umum wajib melakukan diversi, bila tidak berhasil, maka hakim pun wajib melakukan upaya diversi dimaksud (Pasal 15 UU-SPPA). Selama anak-anak menjalani proses peradilan, maka anak-anak tersebut diletakkan di Lembaga Penempatan Anak Sementara (selanjutnya disingkat LPAS). Bila diversi tidak berhasil atau kesepakatan diversi tidak dilaksanakan, maka proses pengadilan anak dilanjutkan.

Polisi, jaksa, dan hakim yang melaksanakan penyidikan, penuntutan dan pemeriksaan adalah penyidik anak, penuntut umum anak, dan hakim anak, termasuk pula hakim banding anak dan hakim kasasi anak. Dalam ketentuan Pasal 92 ayat (1) menyebutkan bahwa pemerintah wajib menyelenggarakan pendidikan dan pelatihan bagi penegak hukum dan pihak terkait secara terpadu, hal ini dimaksudkan bahwa para penegak hukum adalah mereka yang secara profesional adalah penegak hukum yang mempunyai sensitifitas terhadap anak-anak.

Berlakunya UU-SPPA mengupayakan tidak ada lagi bentuk-bentuk menahan anak di rumah tahanan seperti sekarang, penyidik nanti mengupayakan dua pihak melakukan perdamaian dengan atau tanpa ganti rugi, hukuman berupa penyerahan anak kembali ke orangtua, hukuman berupa pelayanan masyarakat, atau penyerahan ke lembaga pendidikan.

Begitu pula pengaturan batasan minimal anak yang bisa dimintai pertanggungjawaban hukum pidana dari awalnya delapan tahun menjadi dua belas tahun sampai delapan belas tahun (Pasal 21 UU-SPPA - sejalan dengan Putusan MK Nomor 1/PUU-VIII/2010). Sementara itu, batasan minimal anak yang bisa ditahan adalah empat belas sampai delapan belas tahun (Pasal 32 ayat (2a) UU-SPPA).

Beberapa perangkat hukum harus dipersiapkan dalam rangka memberlakukan UU-SPPA, baik secara fisik maupun nonfisik. Secara fisik meliputi meliputi Lembaga Pembinaan Khusus Anak (yang selanjutnya disebut LPKA) adalah lembaga atau tempat anak menjalani masa pidananya, LPAS adalah tempat sementara bagi anak selama proses peradilan berlangsung, Lembaga Penyelenggara Kesejahteraan Sosial (yang selanjutnya disebut LPKS) adalah lembaga atau tempat pelayanan sosial yang melaksanakan penyelenggaraan kesejahteraan sosial bagi anak, ruang khusus penyidikan anak yang bernuansa anak-anak, ruang tunggu khusus sementara menunggu persidangan, kebutuhan tersebut sudah harus ada seiring berlakunya UU-SPPA. Sedangkan kebutuhan nonfisik meliputi ketersediaan Sumber Daya Manusia yang meliputi perangkat hukum yang telah terdidik dan memiliki sensitifitas terhadap anak yaitu penyidik anak, jaksa anak dan hakim anak. Begitu pula didukung dengan tersedianya pembimbing kemasyarakatan, pekerja sosial profesional, tenaga kesejahteraan sosial, dan pendamping yang betul-betul dapat memberikan perlindungan terhadap anak-anak yang berada dalam kasus hukum. Terpenuhinya kebutuhan fisik dan nonfisik dalam pasal 105 UUSPPA diberi tenggang waktu 5 (lima) tahun.

Oleh karena itu, lahirnya UU-SPPA merupakan 'harapan' bagi anak-anak yang berhadapan dengan hukum baik sebagai pelaku maupun sebagai korban untuk tetap mendapatkan hak-haknya. Hal penting yang diatur dalam UU-SPPA adalah pelaksanaan diversi yaitu pengalihan penyelesaian pidana anak dari proses peradilan pidana di luar peradilan pidana. Langkah diversi tersebut dimaksudkan untuk memperoleh keadilan restorasi (restoratifjustice) yaitu penyelesaian perkara tindak pidana dengan melibatkan pelaku, korban, keluarga pelaku atau korban, dan pihak lain yang terkait untuk bersama-sama mencari penyelesaian yang adil dengan menekankan pemulihan kembali pada keadaan semula dan bukan untuk pembalasan (Pasal 1 angka 6 UU-SPPA.

Selain untuk menyelesaian konflik, pengalihan penyelesaian pidana melalui diversi itu bertujuan untuk menyadarkan kepada pelaku bahwa tindak pidana yang dilakukan itu tidak dapat dibenarkan dan telah merugikan pihak lain. Oleh karena itu jika diversi berhasil disepakati para pihak-pihak yang terkait terutama pihak korban di tingkat penyidikan (Polres) maka anak (pelaku) akan segera memperoleh pemulihan hak-haknya. Sebaliknya jika belum berhasil diversi akan dilanjutkan di tingkat penyelidikan (Kejaksaan), dan jika tetap belum berhasil diversi akan diteruskan sampai di pengadilan. Pelaksanaan diversi dari masing-masing tahapan itu dibutuhkan waktu maksimal 30 hari. 
Pelaksanaan diversi yang cukup panjang itu menjadi salah satu tantangan bagi pihak-pihak yang terlibat untuk mempersiapkan diri baik secara fisik maupun nonfisik. Persiapan nonfisik meliputi kesiapan sumber daya manusia di masing-masing tingkatan, bagaimana mempersiapkan penyidik anak, jaksa anak, dan hakim anak. Demikian juga persiapan fisik yang meliputi sarana ruang khusus penyidikan atau pemeriksaan yang bernuansa anakanak, LPKA yaitu tempat yang dipergunakan untuk menjalani masa pidana anak karena anak-anak titak boleh ditempatkan dalam lembaga penasyarakatan, LPAS yaitu tempat sementara bagi anak selama proses peradilan berlangsung, LPKS yaitu lembaga tempat pelayanan sosial yang melaksanakan penyelenggaraan kesejahteraan bagi anak. Apakah semua persiapan itu telah dilakukan oleh penegak hukum di Pamekasan mengingat waktu efektif pemberlakuan UU-SPPA sudah dekat yaitu tanggal 30 Juli 2014.

\section{PERUMUSAN MASALAH}

Berdasarkan paparan di atas, dapat dirumuskan fokus penelitian sebagai berikut: Pertama, Bagaimana pemahaman penegak hukum di Kabupaten Pamekasan atas UU-SPPA; Kedua, Bagaimana persiapan penegak hukum di Kabupaten Pamekasan dalam pemberlakuan UU-SPPA; dan Ketiga, Apa saja faktor pendukung dan penghambat kesiapan penegak hukum di Kabupaten Pamekasan atas pemberlakuan UU-SPPA.

\section{METODE PENELITIAN}

Pendekatan dalam penelitian ini menggunakan pendekatan kualitatif (qualitative approach) karena data yang dikumpulkan lebih banyak menggunakan data kualitatif yakni data yang disajikan dalam bentuk verbal bukan dalam bentuk angka (Noeng Muhadjir, 1996:29) yang semaksimal mungkin berusaha mendeskripsikan realitas aslinya untuk kemudian data dimaksud dianalisis dan diabstraksikan dalam bentuk teori sebagai tujuan finalnya.

Penelitian ini merupkan penelitian deskriptif. Tujuannya untuk memberikan data yang seteliti mungkin tentang manusia, keadaan atau gejala yang lainnya (Soerjono Soekamto, 1988:42). Metode deskriptif dimaksudkan memperoleh gambaran yang benar dan jelas, sehingga dapat memberikan data seteliti mungkin tentang obyek yang diteliti, untuk menggambarkan kesiapan penegak hukum dalam pemberlakuan UU-SPPA.
Pada penelitian kualitatif juga ditandai dengan menggunakan metode pengumpulan data yang berupa participant observation dan indepth interview sebagai instrumen pengumpulan data utama. Pendekatan kualitatif yang digunakan bersifat multimetode dalam fokusnya dan menggunakan pendekatan alamiah serta penafsiran terhadap pokok permasalahan yang diteliti. Pemilihan pendekatan ini dianggap tepat karena yang diinginkan peneliti adalah permasalahan dalam setting alamiah dan berusaha untuk memaknai dan menafsirkan fenomena yang ada berdasarkan apa yang dirasakan oleh para informan. Dengan menggunakan pendekatan kualitatif ini diharapkan dapat memperoleh pemahaman yang mendalam dan murni tentang fenomena yang diteliti, dan ini tidak mungkin dapat diperoleh jika tidak menggunakan pendekatan kualitatif.

Selain pendekatan kualitatif yang dipergunakan dalam penelitian ini, peneliti juga menggunakan pendekatan-pendekatan dalam penelitian hukum yaitu pendekatan undang-undang (statute approach), pendekatan kasus (case approach), pendekatan historis (historical approach), dan pendekatan konseptual (conceptual approach) (Peter Mahmud Marzuki, 2005:92).

\section{PEMBAHASAN}

Penelitian ini menghasilkan temuan bahwa keberlakukan sebuah undang-undang tidak berhenti pada telah diundangkannya sebuah undang-undang oleh lembaga legislasi nasional yaitu lembaga negara yang terhormat DPR RI, tetapi masih banyak hal yang harus dipersiapkan baik dari kesiapan Sumber Daya Manusia penegak hukum, sarana prasarana, bahkan yang sangat penting adalah kesiapan dari masyarakat sebagai pihak yang terkena hukum itu. Keikutsertaan masyarakat dalam pembuatan produk hukum akan membangun akseptan dan diharapkan mampu mereduksi serendah mungkin tingkat resistensinya, sehingga akan menjadi produk hukum yang ideal. Keikutsertaan masyarakat dalam proses pembentukannya menjadi faktor penyeimbang dengan komponen pembuat produk hukum lainnya (Dikutip dari analisis-terhadap-uu-no3tahun-1997.html hari Rabu tanggal 28 Agustus 2013 Jam 22.00 WIB).

\section{Pemahaman Penegak Hukum di Kabupaten Pamekasan atas Pemberlakuan UU-SPPA}

Berdasarkan hasil penelitian dari tiga institusi penegak hukum yaitu penyidik kepolisian, jaksa 
penuntut umum dan hakim di Pengadilan Agama. Hampir semua penegak hukum di Kabupaten Pamekasan yang terdiri dari penyidik atau polisi yaitu Kepala Unit Perlindungan Perempuan dan Anak, Kasat Reskrim Polres Pamekasan sebagai informan dalam penelitian ini, Jaksa di Kejaksaan Negeri Pamekasan dan Hakim di Pengadilan Negeri Pamekasan menyatakan bahwa mereka sudah memahami tentang UUU-SPPA. Pemahaman itu mereka dapatkan melalui acara sosialisasi dan seminar-seminar yang dilakukan oleh Kementerian Hukum dan HAM maupun melalui browsing di Internet. Menurut mereka pemberlakuan UU-SPPA memang bagus untuk memberikan perlindungan kepada anak-anak yang berhadapan dengan hukum sebagai penyempurna atas pelaksanaan Undang-Undang Nomor 3 Tahun 1997 tentang Pengadilan Anak yang berlaku selama ini.

Jangka waktu 2 (dua) tahun untuk memberikan kesempatan dalam persiapan berlakunya UU-SPPA dapat dikata waktu yang cukup atau pun tidak cukup. Dikatakan cukup bilamana masing-masing penegak hukum betul-betul telah mempersiapkan diri untuk mendalami pemahaman apa yang menjadi amanah UUSPPA. Seperti asas restoratif justice yang merupakan asas yang menjadi tujuan utama berlakunya UU-SPPA, dengan asas restoratifjustice merupakan upaya penting yang harus ditempuh dalam penyelesaian kasus-kasus anak dengan cara penyelesaian perkara tindak pidana dengan melibatkan pelaku, korban, keluarga pelaku/ korban, dan pihak lain yang terkait untuk bersama-sama mencari penyelesaian yang adil dengan menekankan pemulihan kembali pada keadaan semula dan bukan pembalasan (Pasal 1 angka 6 UU-SPPA). Untuk itu semua penegak hukum di tingkat kepolisian, jaksa, dan hakim diwajibkan untuk melakukan diversi yaitu pengalihan penyelesaian perkara anak dari proses peradilan pidana ke proses di luar peradilan pidana. Diversi ini dalam Undang-Undang Perlindungan Anak sudah diharapkan diterapkan akan tetapi lebih ditekankan pada saat proses penyidikan di tingkat kepolisian, sedangkan dalam UU-SPPA memberikan kewajiban pada setiap tahapan baik di tingkat penyidikan kepolisian, penuntutan di kejaksaan dan pemeriksaan di persidangan. Pengadilan para penegak hukum harus mengupayakan diversi, bilamana tidak berhasil, maka proses persidangannya dapat dilanjutkan.

Mengingat kultur masyarakat Indonesia dengan sistem sosial budaya yang sangat majemuk (plural society) dan berbagai macam stratifikasi sosial. Banyak masyarakat yang tinggal di daerah pedesaan dengan berbeda karakteristik masyarakat perkotaan, maka bilamana kita berbicara tentang hukum yang harus ditegakkan, maka akan menjadi percuma kalau tidak melibatkan masyarakat yang pluralistik tersebut terlebih masyarakat kita sekarang berada pada masa transisi perubahan yang sangat fenomenal (Sabian Utsman, 2008:25).

Hal yang penting pula untuk dipahami dalam pemberlakuan UU-SPPA bahwa peran serta masyarakat juga diharapkan baik memberikan perlindungan terhadap anak-anak mulai dari pencegahan sampai dengan reintegrasi sosial anak dengan cara: 1 . menyampaikan laporan terjadinya pelanggaran hak anak kepada pihak yang berwenang; 2 . mengajukan usulan mengenai perumusan dan kebijakan yang berkaitan dengan anak; 3. melakukan penelitian dan pendidikan mengenai anak; 4. berpartisipasi dalam penyelesaian perkara anak melalui diversi dan pendekatan keadilan restroaktif; 5. berkontribusi dalam rehabilitasi dan reintegrasi sosial anak, anak korban dan/atau anak saksi melalui organisasi kemasyarakatan; 6. melakukan pemantauan terhadap kinerja aparat penegak hukum dalam penanganan perkara anak; atau 7. melakukan sosialisasi mengenai hak anak serta peraturan perundang-undangan yang berkaitan dengan anak (Pasal 93 UU-SPPA).

\section{Persiapan yang Sudah Dilakukan oleh Penegak Hukum di Kabupaten Pamekasan dalam Pemberlakuan UU-SPPA}

Dalam rangka pelaksanan UU-SPPA sesuai dengan amanahnya ada beberapa sarana dan prasarana yang harus ada. Kebutuhan sarana dan prasarana ini menjadi wajib ada berkaitan dengan proses dalam penanganan kasus-kasus anak yang berhadapan dengan hukum. Berlakunya UU-SPPA tinggal menunggu beberapa bulan lagi tepatnya tanggal 30 Juli 2014 sudah harus diberlakukan. Perencanaan anggaran untuk memenuhi falititas tersebut seharusnya sudah dianggarkan pada anggaran tahun 2013 oleh masing-masing institusi penegak hukum.

Pesiapan pemberlakuan UU-SPPA tersebut terdiri dari dua aspek, yaitu fisik dan nonfisik. Persiapan secara fisik meliputi sarana-prasarana dan persiapan secara nonfisik meliputi kesiapan sumber daya manusia penegak hukum dan pihak-pihak yang terlibat lainnya. Hasil penelitian menunjukkan bahwa di Pamekasan 
persiapan secara fisik sementara ini masih belum ada karena semua persiapan itu membutuhkan ketersediaan dana yang tidak sedikit. Semua persiapan fisik itu harus didanai oleh dana DIPA di masing-masing instansi penegak hukum dan sampai sekarang belum ada upaya untuk itu. Demikian juga kesiapan pihak pemerintah daerah yang harus mempersiapkan lembaga-lembaga seperti LPKA yaitu tempat yang dipergunakan untuk menjalani masa pidana anak karena anak yang berhadapan dengan hukum tidak boleh ditempatkan dalam lembaga pemasyarakatan, LPAS yaitu tempat sementara bagi anak selama proses peradilan berlangsung, LPKS yaitu lembaga tempat pelayanan sosial yang melaksanakan penyelenggaraan kesejahteraan bagi anak belum ada tanda-tanda untuk mempersiapkan. Meskipun demikian, penegak hukum di Pamekasan menyatakan kesiapannya jika pada waktunya UU-SPPA sudah harus diberlakukan.

Persiapan nonfisik yang sudah dilakukan oleh penegak hukum di Pamekasan adalah memberikan pemahaman melalui sosialisasi dan mengirimkan namanama pihak yang diminta oleh Kementerian hukum dan HAM. Langkah ini untuk persiapan pelaksanaan pelatihan ataupun pendidikan bagi penegak hukum yang akan bertindak baik sebagai penyidik, penuntut umum ataupun hakim yang mempunyai kepekaan atau sensitifitas terhadap anak-anak.

Beberapa substansi yang harus secara tegas ditentukan dalam perundang-undangan antara lain, penempatan anak yang menjalani proses peradilan dapat ditempatkan dalam tempat penahanan khusus anak, lembaga sosial, dan/atau lembaga pemasyarakatan khusus anak (lembaga pembinaan khusus anak). Dan yang paling mendasar dalam UU-SPPA adalah pengaturan secara tegas mengenai restorative justice dan diversi. Pengaturan mengenai diversi dimaksudkan antara lain untuk menghindari atau menjauhkan anak dari proses peradilan. Hal ini antara lain bertujuan untuk menghindari stigmatisasi terhadap anak yang diduga melakukan tindak pidana, sehingga diharapkan anak dapat kembali ke dalam lingkungan sosialnya secara wajar. Oleh karena itu sangat diperlukan peran serta semua pihak dalam rangka mewujudkan hal tersebut.

Faktor Pendukung dan Penghambat Kesiapan Penegak Hukum dalam pelaksanaan UU-SPPA

Pelaksanaan UU-SPPA sesuai dengan amanatnya akan diberlakukan tanggal 30 Juli 2014, faktor yang memberikan kontribusi dukungan atas pemberlakuan UU-SPPA adalah bahwa selama ini telah diberlakukan Undang-Undang Perlindungan Anak. Undang-undang telah mengakomodir kepentingan dan perlindungan anak dan selama ini telah mewarnai penyelesaian kasus-kasus anak yang berhadapan dengan hukum. Faktor penghambat atas pemberlakuan UU-SPPA yang paling dominan justru ada pada UU-SPPA itu sendiri karena masih banyak aturan yang memerlukan petunjuk teknis untuk melaksanakannya, seperti aturan tentang prosedur diversi. Jika diversi merupakan amanat dalam UU-SPPA, maka selama lembaga-lembaga baru seperti LPKA yaitu tempat yang dipergunakan untuk menjalani masa pidana anak karena anak yang berhadapan dengan hukum tidak boleh ditempatkan dalam lembaga pemasyarakatan, LPAS yaitu tempat sementara bagi anak selama proses peradilan berlangsung, LPKS yaitu lembaga tempat pelayanan sosial yang melaksanakan penyelenggaraan kesejahteraan bagi anak belum tersedia, maka pelaksanaan diversi akan mengalami hambatan, dimana anak harus ditampung. Demikian juga selama belum tersedia penegak hukum khusus anak yaitu penyidik anak, jaksa anak, dan hakim anak yang mempunyai sensitifitas terhadap anak, maka amanat UU-SPPA juga tidak akan terlaksana.

\section{PENUTUP}

\section{Kesimpulan}

Berdasarkan hasil temuan dan pembahasan penelitian, maka dapat disimpulkan, bahwa:

Pertama, Hampir semua penegak hukum di Kabupaten Pamekasan yang terdiri dari penyidik polisi, Jaksa, dan Hakim menyatakan bahwa mereka sudah memahami tentang UU-SPPA. Pemahaman itu mereka dapatkan melalui acara sosialisasi dan seminar-seminar yang dilakukan oleh Kementerian Hukum dan HAM maupun melalui browsing di Internet. Menurut mereka pemberlakuan UU-SPPA memang bangus untuk memberikan perlindungan kepada anak-anak yang berhadapan dengan hukum sebagai penyempurna atas pelaksanaan Undang-Undang Nomor 3 Tahun 1997 tentang Pengadilan Anak yang berlaku selama ini. Asas restoratif justice merupakan upaya penting yang harus ditempuh dalam penyelesaian kasus-kasus anak. Untuk itu semua penegak hukum di tingkat kepolisian, jaksa, dan hakim diwajibkan untuk melakukan diversi.

Kedua, Persiapan yang sudah dilakukan oleh penegak hukum di Kabupaten Pamekasan dalam 
pemberlakuan UU-SPPA terdiri dari dua aspek, yaitu fisik dan nonfisik. Persiapan secara fisik yang berupa sarana dan prasarana sementara ini masih belum ada karena semua persiapan itu membutuhkan ketersediaan dana yang tidak sedikit. Semua persiapan fisik itu harus didanai oleh dana DIPA di masing-masing instansi penegak hukum dan sampai sekarang belum ada upaya untuk itu. Demikian juga kesiapan pihak pemerintah daerah yang harus mempersiapkan lembaga-lembaga seperti LPKA, LPAS, LPKS. Persiapan nonfisik yang sudah dilakukan oleh penegak hukum di Pamekasan adalah memberikan pemahaman melalui sosialisasi dan mengirimkan nama-nama pihak-pihak yang diminta oleh Kementerian Hukum dan HAM. Langkah ini untuk persiapan pelaksanaan pelatihan ataupun pendidikan bagi penegak hukum yang akan bertindak baik sebagai penyidik, penuntut umum atau pun hakim yang mempunyai kepekaan atau sensitifitas terhadap anak-anak.

Ketiga, Faktor pendukung berlakunya UU-SPPA, undang-undang ini telah mengakomodir kepentingan dan perlindungan anak dan selama ini telah mewarnai penyelesaian kasus-kasus anak yang berhadapan dengan hukum. Sedangkan faktor penghambat atas pemberlakuan UU-SPPA yang paling dominan justru ada pada UU-SPPA itu sendiri karena masih banyak aturan yang memerlukan petunjuk teknis untuk melaksanakannya, seperti aturan tentang prosedur diversi. Jika diversi merupakan amanat dalam UU-SPPA, maka selama lembaga-lembaga baru belum tersedia, maka pelaksanaan diversi akan mengalami hambatan, dimana anak harus ditampung. Demikian juga selama belum tersedia penegak hukum khusus anak, maka amanat UU-SPPA juga tidak akan terlaksana.

\section{Rekomendasi}

Dari kesimpulan tersebut dan dalam rangka pemberlakuan UU-SPPA peneliti memberikan rekomendasi sebagai berikut:

Pertama, Pemerintah dalam hal ini Kementerian Hukum dan HAM seharusnya secepat mungkin untuk melaksanakan sosialisasi secara menyeluruh kepada para penegak hukum baik dari tingkat penyidik kepolisian, kejaksaan, dan pengadilan termasuk pelaksana teknis lainnya seperti Balai Pemasyarakatan tentang UUSPPA.

Kedua, Mengingat waktu yang telah diamanatkan oleh UU-SPPA akan segera diberlakukan, maka bagi pemerintah melalui instansi penegak hukum masingmasing untuk segera melakukan pembentukan dan pemenuhan baik secara fisik maupun nonfisik berupa tersedianya LPKA, LPAS, LPKS, ruang pemeriksaan khusus yang bernuansa anak, ruang tunggu khusus sebelum persidangan, begitu pula pelatihan dan pendidikan bagi penyidik anak, jaksa anak, dan hakim anak.

Ketiga, Pentingnya bagi pemerintah untuk memberikan sosialisasi dan pemahaman kepada masyarakat secara menyeluruh sebagai pihak yang terkena hukum supaya siap untuk memberlakukan UU-SPPA terutama pemahaman atas pelaksanaan Diversi.

\section{DAFTAR PUSTAKA}

\section{Buku:}

Gultom, Maidin. 2008. Perlindungan Hukum terhadap Anak. Bandung: Refika Aditama.

Hadi, Sutrisno. 1990. Metodologi Research. Yogyakarta: Andi Offset.

Moleong, Lexy J. 1990. Metodologi Penelitian Kualitatif. Bandung: Remaja Rosdakarya.

M. Hadjon, Philipus dan Tatiek Sri Djatmiati. 2005. Argumentasi Hukum. Yogyakarta: Gajah Mada University Press.

Marzuki, Peter Mahmud. 2005. Penelitian Hukum. Jakarta: Kencana Prenada Media Group.

Muhadjir, Noeng. 1996. Metode Penelitian Kualitatif. Yogyakarta: Rake Sarasin.

Rahardjo, Satjipto. 2009. Hukum Progresif-Sebuah Sintesa Hukum Indonesia. Yogyakarta: Genta Publishing.

Soekamto, Soerjono. 1988. Pengantar Penelitian Hukum. Jakarta: UI Press.

Spradley, J.P. 1980. Participant Observation. New York: Holt, Rinehart, and Winston.

Supraptiningsih, Umi. 2010. "Penerapan UU No. 23 Tahun 2002 tentang Perlindungan Anak (Studi Kasus terhadap Anak yang Berhadapan dengan Proses Hukum)". Asy-Syir'ah - Jurnal Ilmu Syari'ah. Vol 44 No. II Terakreditasi SK No. 43/DIKTI/Kep/2008.

Sutatiek, Sri. 2013. "Politik Hukum UU No. 11 Tahun 2012 tentang Sistem Peradilan Pidana Anak". Varia Peradilan. No. 328 - Maret.

Utsman, Sabian. 2008. Menuju Penegakan Hukum Responsif. Yogyakarta: Pustaka Pelajar. 


\section{Peraturan Perundang-undangan:}

Undang-Undang Dasar 1945.

Kitab Undang-Undang Hukum Perdata.

Undang-Undang Nomor 4 Tahun 1979 tentang Kesejahteraan Anak.

Undang-Undang Nomor 3 Tahun 1997 tentang Pengadilan Anak.
Undang-Undang Nomor 39 Tahun 1999 tentang Hak Asasi Manusia.

Undang-Undang Nomor 23 Tahun 2002 Perlindungan Anak.

Undang-Undang Nomor 11 Tahun 2012 tentang Sistem Peradilan Pidana Anak. 